\title{
Evaluation of the best environment for the six-minute walk test
}

\author{
Avaliação do melhor ambiente para o teste \\ de caminhada de seis minutos
}

\section{Newton Santos de Faria Júnior ${ }^{[a]}$, Cláudio Hiroshi Nakata ${ }^{[b]}$, Luís Vicente Franco de Oliveira ${ }^{[c]}$, Gaspar Rogério Chiappa ${ }^{[\mathrm{d}]}$, Gerson Cipriano Júnior ${ }^{[\mathrm{b}] *}$}

[a] Universidade do Estado de Minas Gerais (UEMG), campus Divinópolis; Divinópolis, MG, Brazil

[b] Universidade de Brasília (UnB), Brasília, DF, Brazil

[c] Universidade Nove de Julho (Uninove), São Paulo, SP, Brazil

[d] Faculdades da Serra Gaúcha (FSG), Porto Alegre, RS, Brazil

\section{Abstract}

Introduction: The purpose of the six-minute walk test (6MWT) is to evaluate cardiopulmonary capacity using a low-cost test that is easy to administer, generally well tolerated by different populations and reflects one's performance on activities of daily living. However, few studies have been conducted to determine the difference between performing the 6MWT indoors and outdoors. Objective: The aim of the present study was to compare the distance covered on the 6MWT performed indoors and outdoors and evaluate the following physiological variables: heart rate, blood pressure and the subjective sensation of shortness of breath, using the Borg perceived exertion scale. Materials and methods: A prospective, randomized, clinical trial was conducted involving eight healthy females not engaged in regular physical activity, with

\footnotetext{
* NSFJ: PhD, e-mail: nsdfj@yahoo.com.br CHN: MSc, e-mail: fisionakata@gmail.com LVFO: PhD, e-mail: oliveira.lvf@uninove.br GRC: PhD, e-mail: gaspar.chiappa@gmail.com GCJ: PhD, e-mail: ciprianeft@gmail.com
} 
mean age $23.75 \pm 1.67$ years. Each subject performed the 6MWT indoors and outdoors with a 30-minute interval between tests. The order of the tests was determined randomly. Results: The mean distance traveled was $578 \pm 50.07 \mathrm{~m}$ on the outdoor trial and $579.95 \pm 45.35 \mathrm{~m}$ on the indoor trial $(\mathrm{p}=0.932)$. The mean physiological variables were $82.25 \pm 11.02 \mathrm{bpm}$ (indoors) versus $84.38 \pm 9.42 \mathrm{bpm}$ (outdoors) for heart rate, $121.88 \pm 10.28 \mathrm{mmHg}$ (indoors) versus $118.75 \pm 19.40 \mathrm{mmHg}$ (outdoors) for systolic blood pressure, 81.88 $\pm 9.74 \mathrm{mmHg}$ (indoors) versus $80.50 \pm 7.89 \mathrm{mmHg}$ (outdoors) for diastolic blood pressure and a mean score of 12 on the perceived exertion score in both environments. Conclusions: The present data demonstrate no differences in the distance walked on the 6MWT or the physiologic variables of participants between the indoor and outdoor trials.

Keywords: Exercise test. Walking. Physical exertion. Exercise tolerance.

\section{Resumo}

Introdução: $O$ objetivo do teste de caminhada de seis minutos (TC6) é avaliar a capacidade cardiorrespiratória por meio de um teste de baixo custo e de fácil administração, sendo bem tolerado por diferentes populações, e que reflita a realização das atividades da vida diária. Entretanto, poucos estudos têm sido realizados para determinar a diferença entre a realização do TC6 em ambientes fechados e ao ar livre. Objetivo: $O$ presente estudo teve como objetivo comparar a distância percorrida no TC6 realizado em ambientes fechado e ao ar livre e avaliar as seguintes variáveis fisiológicas: frequência cardíaca, pressão arterial e a sensação subjetiva de falta de ar, utilizando a escala de percepção de esforço de Borg. Materiais e métodos: Um ensaio clínico randomizado prospectivo foi conduzido envolvendo oito mulheres saudáveis não praticantes de atividade física regular, com média de idade de 23,75 \pm 1,67 anos. As participantes realizaram o TC6 nos dois ambientes com um intervalo de 30 minutos entre os testes. A ordem dos testes foi determinada aleatoriamente. Resultados: A distância média percorrida foi de 578 $\pm 50,07 m$ ao ar livre e 579,95 \pm 45,35 $m$ no ambiente fechado $(p=0,932)$. As variáveis fisiológicas médias foram $82,25 \pm 11,02 \mathrm{bpm}$ (fechado) versus 84,38 \pm 9,42 bpm (ar livre) para a frequência cardíaca, 121,88 $\pm 10,28 \mathrm{~mm} \mathrm{Hg}$ (fechado) versus 118,75 \pm 19,40 mmHg (ar livre) para a pressão arterial sistólica, 81,88 \pm 9,74 mmHg (fechado) versus $80,50 \pm 7,89 \mathrm{mmHg}$ (ar livre) para a pressão arterial diastólica e uma pontuação média de 12 pontos na escala de esforço percebido em ambos os ambientes. Conclusão: Os dados demonstraram que não há diferenças nas distâncias percorridas ou entre as variáveis fisiológicas dos participantes durante o TC6 nos ambientes fechado e ao ar livre.

Palavras-chave: Teste de esforço. Caminhada. Esforço físico. Tolerância ao exercício.

\section{Introduction}

The first walk tests were described by Cooper in 1968, in which the distance travelled was correlated to oxygen consumption after conducting a 12-minute walk. The six-minute walk test (6MWT) is a valid measure of functional status commonly used for evaluating individuals with chronic obstructive pulmonary disease $(1,2)$. This test is typically administered in an enclosed indoor corridor free of distractions and patients are instructed to travel as far as possible in six minutes (3). However, this environment is somewhat artificial and may not adequately reflect one's performance on activities of daily living.
A number of researchers consider the 6MWT to be a sub-maximum exercise test, the purpose of which is to evaluate functional exercise capacity and tolerance to physical exertion. This test is commonly chosen because it is easier to administer, better tolerated and better reflects activities of daily living than other walk tests (1). The subject is permitted to determine the pace, which is an advantage for those who have physical limitations and cannot tolerate a maximum exercise test. However, walking intensity can be influenced by standardized phrases used for speaking to the patient, as the amount of encouragement and enthusiasm given can lead to as much as a $30 \%$ difference in the distance travelled $(2,4-12)$. 
The 6MWT has also been used as a predictor for heart and lung transplantation, the assessment of functional status in elderly individuals as well as patients with chronic obstructive pulmonary disease and chronic heart failure to determine responses to therapeutic interventions. Moreover, this test seems to have a good correlation with maximum oxygen uptake (peak $\left.\mathrm{VO}_{2}\right)(2,10,13-15)$.

Several studies have shown that the 6MWT can be applied on a treadmill, in a hallway or in an open environment. According to the American Thoracic Society (ATS), the 6MWT should be performed in an indoor environment (hallway) to avoid the influence of climate (10). However, some studies have found significant differences with a normal pace between open and closed environments, with individuals reaching a greater distance in the former (5). While an indoor environment is most often employed for the performance of the 6MWT, few studies have demonstrated the existence of differences between open and closed environments or when the test is performed on a treadmill $(13,16,17)$.

Considering the costs involved in obtaining a specific space for the indoor administration of the 6MWT indoors and the existence of regions that prevent outdoor activities for climatic reasons, it is essential to determine the influence of these two environments on the 6MWT so that this test can be administered in accordance with the convenience of the location.

As it is well known that the physiological responses to exercise differ between men and women, the decision was made to evaluate healthy females in the present study to gain a better understanding of their physiological responses. Thus, the aim of the present study was to compare the performance of healthy females on the 6MWT in open and closed environments based on the distance travelled and physiological variables to determine the possible influence of these environments on the results and provide flexibility in the choice of where the test is to be applied, which may exert an impact on the cost of administering this test.

\section{Materials and methods}

Subjects

This study was conducted at a renowned private hospital in the city of Sao Paulo, Brazil. The sample consisted of eight females selected by convenience. All volunteers read and signed a statement of informed consent. This study received approval from the Human Research Ethics Committee under protocol number 1523/07.

The inclusion criteria were age 22 to 27 years, adequate health status and a sedentary lifestyle, as determined using the International Physical Activity Questionnaire (18). The exclusion criteria were musculoskeletal or neuromuscular problem that significantly limited the ability to walk, cognitive or behavioral disorders, unstable angina, uncontrolled hypertension, severe pulmonary hypertension, a recent history of cardiac arrhythmia or myocardial infarction and any clinical condition that could be exacerbated by physical exertion. In the present study, there were no cases of exclusion of the volunteers.

\section{Procedures and design}

The 6MWT was performed in accordance with the guidelines established by the ATS (2). The equipment required for the test were a chronometer (Technos Skydiver Professional ${ }^{\mathrm{TM}}$, Brazil), measuring tape, pulse oximeter (Tuffsat ${ }^{\mathrm{tm}}$, Sao Paulo, Brazil), heart rate monitor (Polar Frequency Model S810 ${ }^{\mathrm{TM}}$, Finland), sphygmomanometer (BD ${ }^{\mathrm{TM}}$, Germany), stethoscope (Littmann $^{\mathrm{TM}}$ Classic II SE, USA) and scale (Bismark ${ }^{\mathrm{TM}}$, Sao Paulo, Brazil).

The volunteers performed the 6MWT once in a closed environment and once in an open environment. The order of the tests was determined randomly. The outdoor test was performed on a 30-meter track between 8 and 10 am in the morning to avoid exposure to high temperature and the indoor test was performed along a 30-meter track in a closed corridor following the recommendations of the ATS. The same previously trained examiners monitored all tests. Heart rate and shortness of breath (Borg scale) were determined before (at rest), during (in the $3^{\text {rd }}$ and $6^{\text {th }}$ minute of the test) and after the test (each minute during recovery). Blood pressure was determined before (at rest) and after the test (each minute during recovery). The volunteers were instructed to walk from one end of the track to the other at the fastest possible pace for six minutes. The tests were performed with an interval of at least 30 minutes between one test and the other. 
The volunteers were instructed to stop the test if they felt symptoms, such as pain in the lower limbs, tachycardia or other symptoms of discomfort. The pulse oximeter remained on the volunteer to monitor oxygen saturation. The test was interrupted if the desaturation level was lower than $88 \%$ or if $90 \%$ of maximum heart rate was reached. The 6MWT was well tolerated by all volunteers, with no complications during or after the test.

\section{Statistical analysis}

The results were analyzed using the Statistical Package for Social Sciences (SPSS 21.0 for Mac OS, Chicago, USA). The data were expressed as mean and standard deviation ( \pm ). Either the paired Student's t-test, ANOVA one-way and Blant-Altman was used for the comparisons between tests, with statistical significance defined as $\mathrm{p}<0.05$.

\section{Results}

Eight healthy women who did not exercise regularly participated in the present study. Table 1 displays the anthropometric characteristics of the sample.

Table 1 - Characteristics of volunteers $(n=8)$

\begin{tabular}{lc}
\hline & Mean (士) \\
\hline Female gender & 8 \\
Age (years) & $23.75(1.67)$ \\
Weight $(\mathrm{kg})$ & $60.81(11.36)$ \\
Height $(\mathrm{m})$ & $1.60(0.05)$ \\
BMl $\left(\mathrm{kg} / \mathrm{m}^{2}\right)$ & $23.56(4.24)$ \\
\hline
\end{tabular}

Note: $\pm=$ standard deviation; BMI = body mass index.

Mean systolic blood pressure (SBP) at rest was $115.38 \pm 10.43 \mathrm{mmHg}$ in the open environment and $112.88 \pm 12.69 \mathrm{mmHg}$ in the closed environment. At the end of the 6MWT, mean SBP had increased to $118.75 \pm 19.40 \mathrm{mmHg}$ in the open environment and $121.88 \pm 10.28 \mathrm{mmHg}$ in the closed environment. Mean SBP decreased in the $6^{\text {th }}$ minute of recovery to $113.38 \pm 13.11 \mathrm{mmHg}$ in the open environment and
$114.063 \pm 16.80 \mathrm{mmHg}$ in the closed environment. No significant differences between environments were found regarding this variable at any evaluation time (Figure 1).

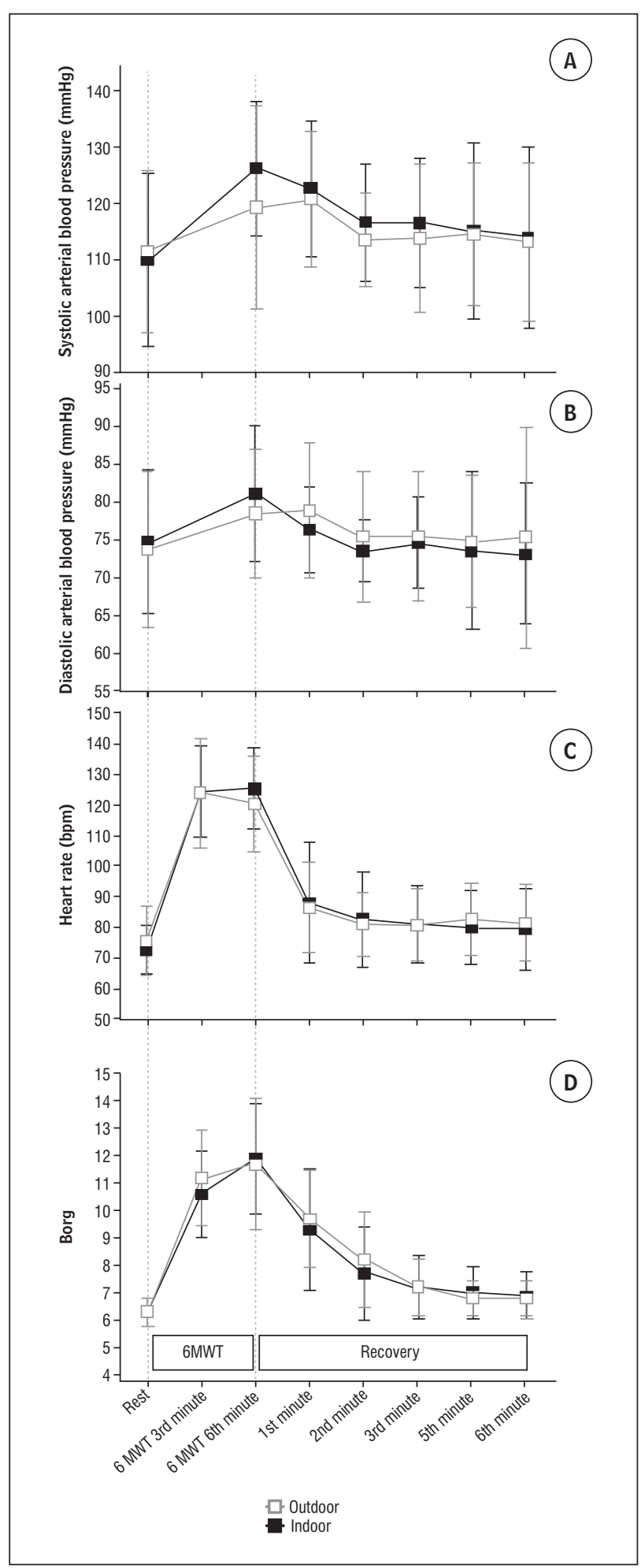

Figure 1 - Physiological data obtained during 6MWT in open and closed environments 
Mean diastolic blood pressure (DBP) at rest was $76.00 \pm 9.69 \mathrm{mmHg}$ in the open environment and $76.13 \pm 8.88 \mathrm{mmHg}$ in the closed environment. At the end of the 6MWT, mean DBP had increased to $76.13 \pm$ $8.88 \mathrm{mmHg}$ in the open environment and $81.88 \pm$ $9.74 \mathrm{mmHg}$ in the closed environment. Mean DBP decreased in the $6^{\text {th }}$ minute of recovery to $77.00 \pm$ $15.58 \mathrm{mmHg}$ in the open environment and $74.88 \pm$ $9.10 \mathrm{mmHg}$ (lower than baseline value) in the closed environment. No significant differences between environments were found regarding this variable at any evaluation time (Figure 1).

Mean heart rate (HR) at rest was $77.75 \pm 7.34$ bpm in the open environment and $74.75 \pm 6.49 \mathrm{bpm}$ in the closed environment. Peak HR was achieved in the $3^{\text {rd }}$ minute of the test in the open environment (126.38 \pm 18.27) and closed environment (127.50 \pm 13.78). HR did not return to baseline values in the $6^{\text {th }}$ minute of recovery $(84.38 \pm 9.42 \mathrm{bpm}$ in the open environment and $82.25 \pm 11.02 \mathrm{bpm}$ in the closed environment). No significant differences between environments were found regarding this variable at any evaluation time (Figure 1).

In both environments, the mean Borg perceived exertion score was 6 (range: 6 to 7 ) at rest, reaching a peak of 12 (range: 9 to 13 ) in the $6^{\text {th }}$ minute of the test and dropping to 7 (range: 6 to 7 ) in the $6^{\text {th }}$ minute of recovery. No significant differences were found regarding this variable at any evaluation time (Figure 1).

The mean distance traveled was $578 \pm 50.07 \mathrm{~m}$ in the open environment and $579.95 \pm 45.35 \mathrm{~m}$ in the closed environment. No significant difference was found regarding this variable (Figure 2).

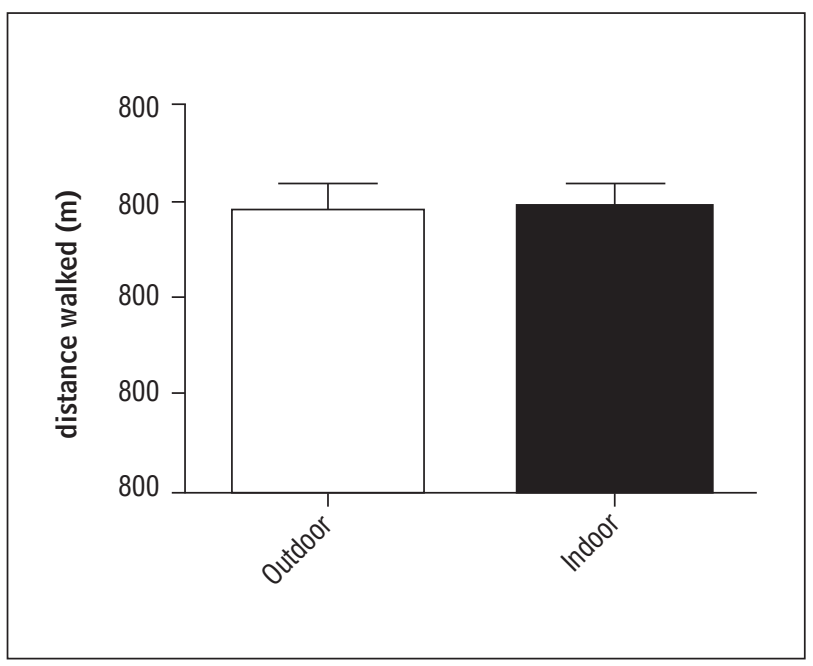

Figure 2 - Distance travelled in both environments

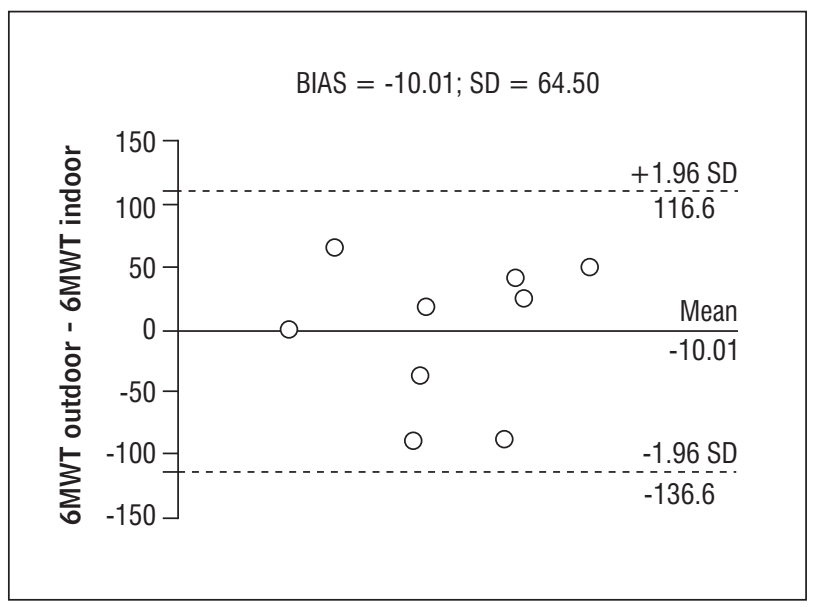

Figure 3 - Bland-Altman plots showing the walking distance difference on 6-min walk test between outdoor and indoor

Statistical analysis Bland-Altman visualize three participants with relevant differences in distances traveled in closed and open environment.

\section{Discussion}

The present study compared the distance covered by healthy females on the 6MWT in closed and open environments as well as the behavior of physiological variables: heart rate, blood pressure and the subjective sensation of shortness of breath using the Borg scale of perceived exertion. The main finding was the lack of differences between environments for all variables analyzed.

The 6MWT has gained importance in the assessment of functional exercise capacity in patients with chronic respiratory disease $(2,10)$. Exercise capacity varies with age, sex and health status (18). Important differences in the distance travelled have been observed in studies performed with healthy subjects (19). Casanova et al. (20) found that males walked a mean distance of 30 meters farther than females and proposed new reference curves for the use of distance on the 6MWT in clinical practice. Furthermore, exercise capacity is a powerful predictor of the prognosis in males with known or suspected coronary disease. Similar findings are described for women, but fewer studies have used peak $\mathrm{VO}_{2}$, which is the most accurate measure of exercise capacity (21). Ades et al. (22) found that peak $\mathrm{VO}_{2}$ diminished progressively with age in both men and women from the third through 
the eighth decades of life and was significantly higher in men than women.

Few studies are found in the literature comparing the 6MWT in a closed environment to the test performed on a treadmill. Swerts et al. (23) concluded that a corridor is more appropriate and efficient than a treadmill, whereas Stevens et al. (24) found no significant differences between the two methods. Cruz et al. (5) found significant differences in distance travelled at a normal pace between open and closed environments, with individuals reaching greater distances in the former. Brooks et al. (6) concluded that the test in an open environment reflects the same indexes as those found in a closed environment provided that the climatic variables are stable.

The differences among the female volunteers regarding age, height and body mass index were non-significant, which is in agreement with data described in a study by Enright et al. (10). To avoid the influence of the learning effect, motivation and environmental factors, the tests were performed following the ATS guidelines, without accompanying the volunteer along the track, only using standardized encouraging phrases, randomizing the order of the tests and always holding the tests in the morning to avoid high temperatures.

Changes occurred in SBP and DBP during the tests, which lead to important physical exercise and hemodynamic autonomic adaptations that influence the cardiovascular system in order to maintain cellular homeostasis in the face of increased metabolic demands. There is an increase in cardiac output, a redistribution of blood flow and increased circulatory perfusion to the exercising muscles. SBP increases directly in proportion to the increase in cardiac output. DBP reflects the efficiency of the local mechanism of vasodilator activity in muscles, which is higher when local capillary density is greater. Vasodilatation in skeletal muscle decreases peripheral resistance to blood flow. Concomitant vasoconstriction, which occurs in tissues not exercised sympathetically, compensates for the induced vasodilatation. Consequently, the overall resistance to blood flow drops drastically at the onset of exercise.

HR increased during the test, with a decrease throughout the recovery period, but without returning to the baseline value after six minutes. The rise in HR during the test is due to the combination of vagal withdrawal and sympathetic activation. The decline in HR immediately after the test is considered to be due to the reactivation of parasympathetic function. This increase in vagal activity has been associated with reduced risk of death, which makes HR recovery at the end of a test as an important prognostic marker, according to Cole et al. (25). The Borg scale of perceived exertion also demonstrated an increase during the test, as expected, with the return to baseline values within the first minute of recovery. Although the differences were non-significant, HR and SBP were higher during and after the test in the closed environment, despite the wide range of environmental factors that could influence the test results in the open environment.

Cruz et al. (5) report that the subjects walked farther in an open environment than a closed environment. However, the study cited divided the 6MWT into normal walking and fast walking. This goes against the guidelines of the ATS, which stipulate instructing the individual to walk as quickly as possible in six minutes. Pires et al. (8) found that younger people with a body mass index $<25 \mathrm{~kg} / \mathrm{m}^{2}$ walked farther. Likewise, the young volunteers in the present study had a mean body mass index 23.54 $\mathrm{kg} / \mathrm{m}^{2}$. Troosters et al. (19) attributed the variability in the distance travelled to height, weight, gender and age, suggesting that these variables should be considered when comparing the results obtained by different individuals.

No significant difference was found regarding the distance traveled in the closed and open environments but the Bland-Altman statistical analysis points to a potential difference in the distances between closed and open environment, as three of the eight participants showed significant clinical differences in the distances.

The 6MWT demonstrates moderate correlation with peak $\mathrm{VO}_{2}$ levels, and ability to predict $\mathrm{VO}_{2}$ (functional capacity) dependent on distance walked. In previous studies, the $6 \mathrm{MWD} \leq 300 \mathrm{~m}$ was significantly able to predict likelihood of death or poorer outcomes in 6 months and worse prognostic outcomes (26). Other studies determined that distances $\leq 450 \mathrm{~m}$ and $\leq 490 \mathrm{~m}$, respectively also correlated with $\mathrm{VO}_{2} \max (27)$.

The small sample size was a limitation of this study and therefore further studies with a larger number of individuals are needed to confirm the similar results when performing the 6MWT in an open or closed environment. 


\section{Conclusion}

The present data demonstrate no differences in the distance walked on the 6MWT or the physiologic variables (heart rate, blood pressure and subjective sensation of shortness of breath) of participants when performed in an indoor or outdoor environment. However, this research needs to be conducted with a larger number of participants to confirm or not the trend indicated by the Bland-Altman statistical test. These findings suggest flexibility in choosing the environment for the test, considering cost and the availability of space at each hospital or rehabilitation center. The open environment allows the administration of the test in locations outside a hospital, whereas a closed environment is more feasible in locations where climatic factors may impede the administration of the test outdoors.

\section{References}

1. Solway S, Brooks D, Lacasse Y, Thomas S. A qualitative systematic overview of the measurement properties of functional walk tests used in the cardiorespiratory domain. Chest. 2001;119(1):256-70.

2. ATS Committee on Proficiency Standards for Clinical Pulmonary Function Laboratories. ATS Statement: guidelines for the six-minute walk test. Am J Respir Crit Care Med. 2002;166(1):111-7.

3. Guyatt GH, Thompson PJ, Berman LB, Sullivan MJ, Townsend M, Jones NL, et al. How should we measure function in patients with chronic heart and lung disease? J Chronic Dis. 1985;38(6):517-24.

4. Araújo CO, Makdisse MRP, Peres PAT, Tebexreni AS, Ramos LR, Matsushita AM, et al. Different patterns of the test and six-minute walk test to measure exercise capacity of elderly patients with and without clinically evident CHD. Arq Bras Cardiol. 2006;86(3):198-205.

5. Cruz MNP, Flores MED, Pérez AR, Hernández JG. Diferencia de la prueba de caminada de 6 minutos entre un espacio abierto y uno cerrado. Rev Int Nal Enf Resp Mex. 2001;14(1):16-21.
6. Brooks D, Solway S, Weinacht K, Wang D, Thomas S. Comparison between an indoor and an outdoor 6-minute walk test among individuals with chronic obstructive pulmonary disease. Arch Phys Med Rehabil. 2003;84(6):873-6.

7. Cipriano Junior G, Yuri D, Bernardelli GF, Mair V, Buffolo, White JNR. Safety assessment of the walk test six minutes in patients undergoing cardiac transplantation. Arq Bras Cardiol. 2009;92 (4):312-9.

8. Pires SR, Oliveira AC, Parreira VF, Britto RR. Test sixminute walk at different ages and body mass indices. Rev Bras Fisioter. 2007;11(2):147-51.

9. Toledo A, Ribeiro K, Silva AB, Costa D. Comparaçao entre o teste de caminhada de seis minutos no corredor e na esteira rolante. Fisioter Bras. 2005,6(1):41-5.

10. Enright PL. The six minute walk test. Respir Care. 2004;48(8):783-5.

11. Baughman RP, Sparkman BK, Lower EE. Six-minute walk test and health status assessment in sarcoidosis. Chest. 2007;132(1):207-13.

12. Ross RM, Murthy JN, Wollak ID, Jackson AS. The six minute walk test accurately estimates mean peak oxygen uptake. BMC Pulm Med. 2010;10:31.

13. Passantino A, Lagioia R, Mastropasqua F, Scrutinio D. Short-term change in distance walked in $6 \mathrm{~min}$ is an indicator of outcome in patients with chronic heart failure in clinical practice. J Am Coll Cardiol. 2006; 48(1):99-105.

14. Ganagaram V. Six minute walk distance is a useful predictor of survival in lung transplant recipients. Thorax. 2008;63(12):1089-93.

15. Cote CG, Casanova C, Marín JM, Lopez MV, Pinto-Plata V, de Oca MM, et al. Validation and comparison of reference equations for the 6-min walk distance test. Eur Respir J. 2008;31(3):571-8.

16. Wise RA, Brown CD. Minimal clinically important differences in the six-minute walk test and the incremental shuttle-walking test. COPD. 2005;2(1):125-9.

17. Guyatt GH, Sullivan MJ, Thompson PJ, Fallen EL, Pugsley SO, Taylor DW, et al. The six-minute walk: a new measure of exercise capacity in patients with chronic heart failure. Can Med Assoc J. 1995;132(8):919-23. 
18. Matsudo SM, Araújo T, Matsudo V, Andrade D, Andrade E, Oliveira LC, et al. Questionário Internacional de Atividade Física (IPAQ): estudo de validade e reprodutibilidade no Brasil. Rev Bras Ativ Fis Saúde. 2001;6(2):5-18.

19. Gulati M, Black HR, Shaw LJ, Arnsdorf MF, Merz CN, Lauer MS, et al. The prognostic value of a nomogram for exercise capacity in women. N Engl J Med. 2005;353(5):468-75.

20. Casanova C, Celli BR, Barria P, Casas A, Cote C, de Torres JP, et al. The 6-min walk distance in healthy subjects: reference standards from seven countries. Eur Respir J. 2010;37(1):150-6.

21. Kavanagh T, Mertens DJ, Hamm LF, Beyene J, Kennedy J, Corey $\mathrm{P}$, et al. Peak oxygen intake and cardiac mortality in women referred for cardiac rehabilitation. J Am Coll Cardiol. 2003;42(12):2139-43.

22. Ades PA, Savage PD, Brawner CA, Lyon CE, Ehrman JK, Bunn JY, et al. Aerobic capacity in patients entering cardiac rehabilitation. Circulation. 2006;113(23):2706-12.

23. Swerts PM, Mostert R, Wouters EF. Comparison of corridor and treadmill walking in patients with severe chronic obstructive pulmonary disease. Phys Ther. 1990;70(7):439-42.
24. Stevens D, Elpern E, Sharma K, Szidon P, Ankin M, Kesten S. Comparison of hallway and treadmill six-minute walk tests. Am J Respir Crit Care Med. 1999;160(5 Pt 1):1540-3.

25. Cole CR, Blackstone EH, Pashkow FJ, Snader CE, Lauer MS. Heart-rate recovery immediately after exercise as a predictor of mortality. N Engl J Med. 1999; 341(18):1351-7.

26. Pollentier B, Irons SL, Benedetto CM, Dibenedetto AM, Loton D, Seyler RD, et al. Examination of the six minute walk test to determine functional capacity in people with chronic heart failure: a systematic review. Cardiopulm Phys Ther J. 2010;21(1):13-21.

27. Pulz C, Diniz RV, Alves AN, Tebexreni AS, Carvalho AC, de Paola AA, et al. Incremental shuttle and sixminute walking tests in the assessment of functional capacity in chronic heart failure. Can J Cardiol. 2008; 24(2):131-5.

Received: 05/29/2014 Recebido: 29/05/2014

Approved: 04/14/2015 Aprovado: 14/04/2015 